\title{
Rethinking Environmentalism and Apocalypse: Anamorphosis in The Book of Enoch and Climate Fiction
}

\author{
Simone Kotva ${ }^{1, *}$ and Eva-Charlotta Mebius ${ }^{2}$ \\ 1 Faculty of Theology, University of Oslo, Blindernveien 9 Domus Theologica, 0371 Oslo, Norway \\ 2 Department of History, Royal Holloway, University of London, Egham TW20 0BL, UK; \\ eva-charlotta.mebius.13@alumni.ucl.ac.uk \\ * Correspondence: simone.kotva@teologi.uio.no
}

check for updates

Citation: Kotva, Simone, and Eva-Charlotta Mebius. 2021. Rethinking Environmentalism and Apocalypse: Anamorphosis in The Book of Enoch and Climate Fiction. Religions 12: 620. https://doi.org/ $10.3390 /$ rel12080620

Academic Editor: Alison Milbank

Received: 1 July 2021

Accepted: 29 July 2021

Published: 9 August 2021

Publisher's Note: MDPI stays neutral with regard to jurisdictional claims in published maps and institutional affiliations.

Copyright: (c) 2021 by the authors. Licensee MDPI, Basel, Switzerland. This article is an open access article distributed under the terms and conditions of the Creative Commons Attribution (CC BY) license (https:// creativecommons.org/licenses/by/ $4.0 /)$.

\begin{abstract}
Biblical apocalypse has long been a source of contention in environmental criticism. Typically, ecocritical readings of Biblical apocalypse rely on a definition of the genre focused on eschatological themes related to species annihilation precipitated by the judgement of the world and the end of time. In this article, we offer an alternative engagement with Biblical apocalypse by drawing on Christopher Rowland and Jolyon Pruszinski's argument that apocalypse is not necessarily concerned with temporality. Our case study is The Book of Enoch. We compare natural history in Enoch to Jean-Luc Marion's phenomenological analysis of Biblical apocalypse as a way of seeing the world that worries human assumptions about the nature of things and thereby instigates an "anamorphosis" of perception. Following Timothy Morton's adaptation of Marion's idea of anamorphosis as an example of the ecological art of attention, we show how apocalypse achieves "anamorphic attention" by encouraging the cultivation of specific modes of perception-principally, openness and receptivity-that are also critical to political theology. In turn, this analysis of anamorphic attention will inform our rethinking of the relationship between environmentalism and apocalyptic themes in climate fiction today, with special reference to Megan Hunter's The End We Start From.
\end{abstract}

Keywords: apocalypse; temporality; ecotheology; jolyon pruszinski; attention; The Book of Enoch; climate fiction; Jean-Luc Marion; Timothy Morton; Megan Hunter

\section{Introduction}

Biblical apocalypse has long been a source of contention in environmental criticism (Garrard 2001; Garrard 2012, pp. 94-116). Typically, ecocritical readings of Biblical apocalypse rely on a definition of the genre focused on eschatological themes related to species annihilation precipitated by the judgement of the world and the end of time. In this article, we offer an alternative engagement with Biblical apocalypse by drawing on Christopher Rowland's and Jolyon Pruszinski's argument that apocalypse is not necessarily concerned with temporality (Rowland 1982; Pruszinski 2019, 2021). We compare this research to Jean-Luc Marion's phenomenological analysis of Biblical apocalypse as a way of seeing the world that worries human assumptions about the nature of things and thereby instigates an "anamorphosis" of perception (Marion 2016). We argue that temporality is not crucial to the genre's fundamental concern with vision and with the world being seen and revealed. Following Timothy Morton's adaptation of Marion's idea of anamorphosis as an example of the ecological art of attention (Morton 2013, pp. 124-25), we show how apocalypse achieves "anamorphic attention" by encouraging the cultivation of specific modes of perceptionprincipally, openness and receptivity - that are critical also to political theology. In turn, this analysis of anamorphic attention will inform our rethinking of the relationship between environmentalism and apocalyptic themes in climate fiction more broadly.

In rethinking the relationship between Biblical apocalypse and environmentalism we join ranks with the recent movement among ecotheologians to reclaim apocalypse (e.g., Rossing 2005, 2007; Northcott 2007, 2014, pp. 268-316; Perkinson 2015; Keller 
$2018,2021)$ while also investigating this movement's emphasis on temporality. To this end, we draw on alternative approaches to apocalypse in Biblical scholarship and the philosophy of religion. Form-critical approaches to revelation have argued that apocalypse is not necessarily temporal and have questioned whether eschatology is the main theme of Biblical apocalypse. In the 1980s Christopher Rowland's work on Jewish apocalyptic literature and the Second Temple period of early Christianity drew attention to The Book of Enoch as a neglected resource for rethinking Biblical apocalypse (Rowland 1982, pp. 124-35). With this scholarship as our starting point, we argue for the importance of perception and attention to the environment in Biblical apocalypse through a discussion of the presence of natural history in Enoch.

The article falls into three parts. In the first, we introduce the ecocritical ambivalence toward Biblical apocalypse and examine some prominent ecotheological responses. Environmental theologians, we argue, are right to point out that most ecocritical readings of apocalypse are based on a narrow understanding of eschatology. At the same time, we show that environmental theology also encourages selective readings of apocalypse by focussing on temporal themes to the exclusion of the genre's formal features. Moreover, we argue that these formal features do not undermine the political function of apocalypse but rather shapes and informs it in important ways that have still to be explored by scholarship. In the second part, we provide an alternative perspective on the political theology of apocalypse by examining it in relation to Enoch's "critical engagement with the material world" (Pruszinski 2019, p. 10). Enoch contains vivid accounts of the end of time, but the main portion of the text is devoted to natural history and to remembering and recording the world "as it is." Drawing on phenomenological approaches to apocalypse, we analyse Enoch's critical engagement with the world as an "inversion" or anamorphosis of attention occurring as the result of the world being revealed or unveiled. In the third part, we apply our re-reading of Biblical apocalypse to apocalypse in contemporary climate fiction. Reflecting on Megan Hunter's remarkable retelling of Biblical apocalyptic, The End We Start From (Hunter 2017), we show how anamorphosis of attention occurs also in apocalyptic fiction where climate crisis is depicted "as some kind of daily life" and disaster is narrated from the perspective of domesticity (Robinson and Canavan 2014, p. 245). In one sense, we try to answer the question: why read Enoch today? However, we also indicate how, in our contemporary climate fiction, we may already be reading Enoch.

\section{Reclaiming Apocalypse}

In his seminal piece for an early edition of Green Letters, Greg Garrard argued that while Biblical apocalypse continues to supply environmentalism with its most popular rhetoric, there is little doubt that apocalyptic styles of ecological thinking often encourage a narrow focus on dramatic, fast-paced events that ultimately draws attention away from the drawn-out time frames at stake (Garrard 2001, p. 66). Following Lynn White (1967), Garrard suggests that the apocalypse tradition as a whole "may be the key to the question of JudeoChristianity's contribution to environmental problems"; it "brings with it philosophical and political problems that seriously compromise its usefulness" (Garrard 2001, pp. 33, 63).

For Garrard, the trouble with apocalypse is temporality. Apocalypse centres around the idea of "a singular, catastrophic, 'end of time', or even the immediate doom of Western civilization" (Garrard 2001, p. 67). This is a common complaint against climate fiction, and one that is shared by several critics. Talking about the end of the world is not necessarily the best strategy for preventing that end; the result may be just the opposite, as Pascal Bruckner argued in his provocative exposé of environmental apocalypticism (Bruckner 2013). In the first empirical study of climate fiction, Matthew Schneider-Mayerson similarly points out that the connection between reading climate fiction on the one hand and committing to timely political action on the other may not be as straightforward as presumed. Like Garrard, Schneider-Mayerson notes how apocalyptic themes "present an obstacle to successful persuasion and mobilization" (Schneider-Mayerson 2018, p. 489). The connection between Christian apocalypticism and anti-ecological thinking argued by Garrard was 
demonstrated strikingly in the popular Left Behind franchise. Inspired by the novels of Tim LaHaye and Jerry B. Jenkins, Left Behind is set in an alternative present in which faithful Christians are raptured to heaven while the rest of humanity is left to suffer pandemonium (LaHaye and Jenkins 1995). In the wake of the Left Behind novels, Christian apocalypticism has been scrutinised for encouraging "environmental apathy" and even climate denialism, especially among the Christian fundamentalist Right, among whom belief in an imminent rapture and end of time is particularly widespread (Peifer et al. 2014).

In his analysis of environmentalism and the apocalypse tradition Garrard addresses diverse forms of Jewish and Christian theology but focuses on the mode of theology that Garrard identifies as "tragic". The tragic mode interprets apocalypse as a prognostication of actual events. It is associated with The Book of Revelation, with historical and contemporary Christian dispensationalism, and with millenarianism. In climate fiction, it corresponds to dystopian visions of post-apocalyptic futures. For Garrard, the tragic mode in climate fiction represents an especially radical form of environmental rhetoric where the "new creation" of Biblical apocalypse is "blanked out" by secularised interpretations that leave a lamenting earth only the promise of annihilation. In the tragic mode of eco-apocalyptic, there is no hope for a transformation of the world into a better place after the human evil-doers have perished from its surface (Garrard 2001, p. 60).

Competing with the tragic mode of apocalyptic rhetoric is the "comic" mode. In the comic mode, the ending of the world is interpreted as a possibility rather than as a prognostication, so that "environmental apocalypticism, on this view, is not about anticipating the end of the world, but attempting to avert it by persuasive means" (Garrard 2001, p. 55). Garrard traces the comic mode of apocalypse to Augustine and to the spiritual readings of Revelation favoured in patristic exegesis, and gives it higher praise than the tragic mode. In climate fiction, the comic mode may be found in the less bleakly dystopian futures depicted in Ernest Callenbach's Ecotopia (Callenbach 1975) and the novels of Kim Stanley Robinson (e.g., Robinson 2015). However, because history, in Garrard's opinion, does not sustain a distinction between prophecy (tragic mode) and exhortation (comic mode), neither mode of apocalypse can escape the demand for an "ending" to the world, even if that ending is only imagined or imaginary. In either case, apocalypticism for Garrard leads to escapism: the person committed to apocalypticism (whether comic or tragic) is captive to a rhetoric that is diverting their attention from the demands of the present.

Garrard repeats his reading of environmentalism and the apocalypse tradition in his influential study of literary ecology, Ecocriticism (Garrard 2012, pp. 94-116), which has become significant in shaping literary-critical responses to apocalyptic. At the same time, many post-secular philosophers and cultural theorists protest the modern idea of progress and some of them, including Giorgio Agamben, draw explicitly on Biblical apocalypse in order to do so (Agamben 2005; cf. Skrimshire 2019, pp. 73-77). In a recent article, Wallace McNeish has addressed environmental criticism's antipathy to the apocalypse tradition, arguing that it is symptomatic of deeper problems arising as a result of the "secular" assumptions of environmentalism. Typically, McNeish argues, ecocritical interpretations of apocalypse focus exclusively on disaster and "catastrophism," and yet theological treatments of the genre do not support such readings (McNeish 2017, p. 1038). Indeed, within theological discourse apocalypse remains a burning topic, and not only among the Christian Right. Apocalypse has been significant in political theology since the 1960s (e.g., Rahner 1961, pp. 323-46; Moltmann 1967; Pannenberg 1969), and apocalyptic spirituality plays an important role in the recent, major contributions to ecotheology by Michael Northcott (2007, 2014), Catherine Keller (2018, 2021) and James Perkinson (2015) that we will be considering below. Apocalypse also figures significantly in the small but growing body of work documenting the constructive use of Revelation among Christian social workers (Simmons 2009; Dittmer and Sturm 2010; Megoran 2013). As Peter Yoonsuk Paik argues, the Left Behind series' apathy toward the environment sits awkwardly with Biblical creation theology and should be seen as an exception to its imagery rather than its instantiation. Left Behind's escapist perspective is, he reminds, more reminiscent of Gnostic 
dualism than of Christian (or Jewish) beliefs about the goodness of creation (Paik 2003; cf. Trelstad 2018).

Similarly, Barbara Rossing's work on the ecotheology of Biblical apocalypse has insisted on the need to separate prophecy from prediction, and to distinguish the spiritual messages of apocalypse from the literal interpretations proclaimed by fundamentalist Christians, especially in North America (Rossing 2005, 2007). "Prophecy," she reflects, "doesn't mean prediction [ ... ] What we need to do is reclaim the important Biblical apocalyptic voice of protest and hope away from the problematic readings that have become so dominant" in dispensationalist Christianity (Rossing 2007, p. 557, our emphasis).

Much of this eco-theological reclaiming of Biblical apocalypse has been made possible, in turn, by the political readings one finds in the ground-breaking approaches to apocalypse taken in the 1970s by Biblical scholars. John J. Collins' influential project, a redefinition of the genre of apocalypse in Biblical and pseudo-epigraphical sources, helped to establish the idea of apocalypse as counter-imperialist "resistance literature" (Collins 1979; cf. Collins 2016), an approach we see reflected in contemporary ecotheology. Collins emphasised the social function of Biblical apocalypse and the political circumstances in which it originated. Many examples of Biblical apocalypse were written during the Second Temple period when the Jewish peoples were experiencing the negative effects of foreign rule: deprived or robbed of vital connections to ancestral land, Biblical apocalypses express a profound sense of mourning at the devastation of place. Rather than see apocalypse as a literature about disaster and catastrophe, many Biblical scholars today interpret apocalypse as a "theology of resistance" (Portier-Young 2011).

However, Collins also emphasised the connection between the trauma of the Jewish people and the call for a new and transformed world order after the "ending" of time. Eschatology, although not a criterion of the genre for Collins, is nonetheless very central to his interpretation of Biblical apocalypse as political theology. In ecotheological reclaimings of Biblical apocalypse we see this reflected in the emphasis placed on temporality. For Northcott, the theme of newness and urgency in Revelation is especially pertinent to understanding the importance of apocalyptic today. To this end, Northcott treats the concept of the Anthropocene as an apocalyptic invitation to rework human modes of earth-living in radical ways that might change the course of the future. "If climate change is coming," he writes, "and it is coming, even if in the future human beings find ways to slow it down - there is an urgent need to find ways to live in the new world of the Anthropocene which do not involve the continued large-scale sacrifice of distant ecosystems and the stable climate of future generations" (Northcott 2014, p. 305). Michael Northcott's significant work on environmental theology rejects outright the interpretation of apocalyptic as either the "cult of catastrophism" or comic millenarianism. However, temporality remains significant. Northcott argues that "revolutionary messianism" is the key to apocalyptic theology (2014, pp. 268-316): "Building Jerusalem field by field, village by village, town by town, involves spiritual strife in exposing and dethroning empire, and physical and mental struggle in creating and crafting the alternative" (Northcott 2014, p. 305).

Temporality is also an important theme in Keller's Political Theology of the Earth: Our Planetary Emergency and the Struggle for a New Public (Keller 2018). Here, Keller draws on Giorgio Agamben's The Time that Remains: A Commentary on the Letter to the Romans (Agamben 2005). Agamben's essay is a study of the Biblical concept of kairos, or "opportune time." It argues that Paul's theology is concerned not with the formation of a new religion but with the messianic ending of all religious law and the ushering in of a new time- the time of Christ. Keller argues that while apocalypse is not about predicting the end of clock-time it is still about temporality and the experience of temporality. Apocalypse is a reflection on the fact that "time is running out" and Keller sees the genre as a confrontation not with the world's end but with the ending of the world as we know it (Keller 2018, pp. 1-19). In Keller's most recent book, Facing Apocalypse: Climate, Democracy, and Other Last Chances (Keller 2021), a sustained meditation on Revelation expands this interpretation. Here, Keller, similar to Northcott, reflects on the theme of newness in Revelation, compar- 
ing it to birthing and motherhood but also to political, racial and social struggles to rebirth culture, showing the threads that connect apocalypticism to experiences that have been marginalised by being described pejoratively as "other" (Keller 2021; cf. Keller 1983). For Keller, the political theology of Biblical apocalypse and its function as resistance literature are connected intimately to themes of time, eschatology and revolution.

A related approach to apocalypse is taken by Perkinson in his Political Spirituality in an Age of Eco-Apocalypse: Communication and Struggle across Species, Cultures, and Religions (Perkinson 2015). Perkinson views Biblical apocalypse as the expression of an Indigenous theology struggling against empire to claim its voice and reclaim old ways of cohabiting on the land. Jesus is a "peasant resistance movement leader" articulating an "anarchoprimitivism" of a repressed people (Perkinson 2015, pp. 38, 39). Just as in Northcott's and Keller's work, the theme of endings and the promise of newness (revolution) thus become significant. For Perkinson, endangered and enslaved traditions develop "apocalyptic reading practices" in responses to crises, and Biblical apocalypse should be seen as one such reading practice, a "symbolic articulation of the monstrous unease that stirs in the waters of repressed consciousness when large-scale systems of injustice begin to 'achieve' world-ending levels of destruction" (Perkinson 2015, p. 36).

These ecotheological responses amount to a formidable literature that challenges many of the assumptions that shape Garrard's ecocritical scepticism toward the apocalypse tradition. McNeish perhaps puts it best when he concludes, in the article already mentioned: "The Christian apocalyptic traditions shows if the green movement is to retain its radical edge in the twenty-first century, it must...make 'its secret utopian vocation' public to build a politics of millennial hope" (McNeish 2017, p. 1051). Above all, by drawing attention to the geopolitical concerns that gave birth to the genre, ecotheological reclaiming of Biblical apocalypse makes a strong case for the continued relevance of apocalypse in a time when politics and social justice are recognised as inseparable from environmentalism (Yusoff 2018). In this context apocalypse may be seen as a counter-narrative resisting dominant ideas of temporality, rather than as an attempt to escape from the demands of the present through projections into an imagined future. Keller's work in particular shows that temporality and the discourse of the end of time cannot be identified narrowly with either the tragic or comic modes proposed by Garrard.

Temporality, however, is not the only way in which to understand the political theology of Biblical apocalypse. As Christopher Rowland showed already in The Open Heaven: A Study of Apocalyptic in Judaism and Early Christianity (Rowland 1982), "eschatological matters are usually the result of the divine reply to existential questions, whereas the thoughts which are on the mind of the apocalypticists are more concerned with the situation as it is" (Rowland 1982, p. 134; cf. Hall 2009, p. 12). Biblical apocalypses are not necessarily temporal, nor is the theology of resistance present within them always bound up with temporal themes. In a series of recent studies, Jolyon Pruszinski has developed Rowland's position significantly by examining the role played by what he calls textual "ecologies" in Biblical apocalyptic and related literatures. Drawing on perspectives from cognitive psychology and phenomenology, Pruszinski digs deep into the connection between theologies of resistance and what Rowland identified as Biblical apocalypse's "concern with the situation as it is" (Pruszinski 2019, 2021). In Revelation, the imagery of doors opening and closing "leans towards forgetting and disengagement with the known, and traumatised, material world" (Pruszinski 2019, p. 10). Escapism, however, is not the only orientation of Revelation, argues Pruszinski. The imagery of opening and closing doors, while striking, obscures those parts of the text that are devoted to documenting earthly materials and earthly existence. On this point Pruszinski follows Rowland, who argued that once an apocalyptic text is viewed in the light of the place to which its prophet attends, "the interest in the world as it is speaks more of reflection [...] than the urgent expectations of the end of the world, where such interests would be superfluous" (Rowland 1982, p. 126).

Another approach relevant when considering alternative perspectives on apocalypse is form criticism. Form criticism focuses on the style and basic structures, more than 
on the themes, of apocalyptic texts. One important proponent of the form-critical approach to Biblical apocalyptic was Jean Carmignac, who pointed out that the etymology of apocalypse-from the Greek apocalypsis, "unveiling," hence "revelation"—has nothing explicitly to do with temporality. For Carmignac it is visions and the ability to be enraptured by the environment that characterise the genre. Carmignac connects this definition to the fact that while eschatology is a common theme in Biblical apocalypse, it is not ubiquitous. What is ubiquitous is a preoccupation with the cosmos being "shewn" and "envisioned" (Carmignac 1979; for a critical discussion of the form-critical approach, see Collins 2016). For Carmignac, what was subversive about Biblical apocalypse was the prophet's radical openness to God and to the world.

Common to these alternative approaches to Biblical apocalypse is an engagement with a wider range of textual material than is normally cited in ecotheological reclaimings of the genre, which tend to focus on Revelation. Revelation, however, is a condensed narrative where eschatological themes are particularly dominant, meaning that an interpretation of apocalyptic that refers principally to Revelation is likely to overlook the attentiveness to place studied by Rowland and Pruszinski, or the formal features noticed by Carmignac. There are, however, other texts that were influential in the early Christian church and in Jewish theology. Both Rowland and Pruszinski point to The Book of Enoch. Enoch, composed over several centuries from the third century BCE onwards, is one of the oldest and also the longest of the Jewish apocalypses, containing 108 sections in five books. Framed by temporal themes-including a vivid account of humanity's antediluvian "fall" into unsustainable modes of living, and a rapturous vision of the thousand-year reign of the Messiah-the majority of the text is taken up with extensive and detailed "shewings" of plants, animals, minerals, meteorological phenomena and the movements of heavenly bodies. In fact, a large proportion of the content of Enoch is an account of natural history, with an emphasis on astronomy. Another section of the text, the "Apocalypse of the Animals," retells the story of the Jewish people allegorically through the lives of nonhuman creatures, in this way combining attention to nonhuman creatures with attention to human politics.

In what follows, we will be focussing on the most famously eschatological section of Enoch, "The Book of the Watchers," in order to construct an alternative ecocritical interpretation of Biblical apocalyptic. Following Northcott, Keller, Perkinson et al., we agree that Biblical apocalypse is resistance literature, but expand this notion to include the attentiveness to place and the earth "as it is" addressed by Rowland and, more recently, by Pruszinski. Biblical apocalypse will then be shown to be resistance literature on two fronts. On the one hand, Biblical apocalypse resists planet-destroying powers through a vision of their ending and through an imagined, alternative future. On the other hand, and at the same time, apocalypse resists planet-destroying powers through a fine-grained study of the existing relations between humans, plants, animals, planets and stars, in the teeming pluriformity of created life. We will also show how, in Enoch, the extensive and detailed visions of the world "as it is" functions as counter-narratives to the imagined temporalities which are included in this particular apocalypse. There is a degree of critique here immanent to the text itself, with the "naturalist" Enoch warning readers not to take the "prophet" too literally.

\section{Anamorphic Attention in Enoch's "The Book of the Watchers"}

In this section, we explore Biblical apocalyptic as a form of ecological thinking. In keeping with our argument that both ecocriticism and ecotheology miss the mark when they represent apocalypse as temporal, but agreeing with ecotheologians that Biblical apocalypse is a theology of resistance with strong bearing on environmentalism, in this section we seek to rethink the relationship between apocalypse and political theology. We will be doing this by drawing attention to the important, but often overlooked, function of apocalypse as a "visioning" of the present. We read the theme of vision and looking in light of phenomenological and environmental accounts of attentiveness and "attunement" to things, where attunement denotes an ongoing practice that worries ordinary modes 
of perception and so resists the dominance of habitual ways of thinking and acting. Our case study is The Book of Enoch, a apocryphal apocalypse that has hitherto passed almost unnoticed by environmental criticism. Recently, however, Enoch has featured prominently in the ecotheological interpretation of apocalypse by Micah Kiel (2017). Enoch has also been discussed in the environmentally oriented readings of apocalypse by Matthew Goff (2010), Daniel Assefa (2017), Loren T. Stuckenbruck (2017), Mebius (2018-2019, 2020), as well as being mentioned by Pruszinski in his study of Biblical ecologies of perception (Pruszinski 2019, 2021).

As Kiel points out, it is difficult to read Enoch without thinking of the current environmental crisis. The most obvious reason for considering Enoch as a proto-environmentalist text, and the one discussed by Kiel, is the repercussions of "destructive consumption" narrated in the book's opening vision. The famous opening section, "The Book of the Watchers," is a retelling of Genesis 6, and predicts the Noachian flood from the perspective of Noah's great-grandfather, Enoch. Enoch is shown a vision of the Nephilim, a race of antediluvian giants born out of the transgressive relations between human women and angels, the divine "Watchers" of the title. In Enoch, the Nephilim possess a voracious appetite and begin to consume all that 'which the labour of men produced', as well as birds, beasts, reptiles and fishes (Laurence 1838, vol. 7, pp. 12-14, emphasis in the original). They drink their blood, and finally, unable to satisfy their hunger, they resort to eating humans also. As a result, the earth is devastated and its inhabitants suffer. Not only this, but the Watchers teach humans different technologies, such as metallurgy, that allow them to exploit the earth further. In Enoch, the Nephilim's time on earth inaugurates a period of human enlightenment through the introduction of technology, but also a time of moral decadence. God explains to Enoch that there is only one solution to reverse this process. God promises to send a flood that will destroy all living beings on the planet, but vouches to keep Noah and his family safe from harm in the ark.

For Goff and Kiel, what Enoch reports is an environmental eschatology: the tyranny of the Nephilim alludes to the powers of industrialised society to ravage natural resources. The giants are guilty of what today would be described as an overconsumption of natural resources that makes it impossible for humans to cohabit sustainably with other living creatures. Ultimately, in Enoch, it is the corrupt rulers and exploiters who will suffer. "Woe to you who build your houses by the labour of others," the prophet warns (Laurence 1838, vol. 98, p. 13). Moreover, Enoch introduces eschatological themes that remain much the same in later texts such as Revelation. Societies that are built on the exploitation of labour will end in a time of slaughter, when fathers will "be struck down with their children" (Laurence 1838, vol. 98, p. 1). When that time comes, a man "shall not restrain his hand from his children, nor from his children's children; his mercy will be to kill them" (Laurence 1838, vol. 98, p. 2). The infanticide that unsustainable consumption and urbanisation entails will be visited on those who, through their ways of living, have facilitated the exploitation of earth.

The environmental relevance of Enoch, however, is not limited to eschatology. As we have already discussed, judgement of the earth, and the issuing of a new time, are not themes that are ubiquitous in apocalyptic texts. It is on this point that Enoch becomes especially significant. Enoch is a long text and only some parts of it are concerned with temporality. In addition to the Flood vision in "The Book of the Watchers," there is also a brief account of the New Jerusalem in "The Book of Dream Visions" (Laurence 1838, 90.28-42), and a revelation of the Messiah's return to earth in "The Epistle of Enoch" (Laurence 1838, p. 105) — but these are by no means the main portion of the text. The main portion of the text is taken up by several detailed accounts of the earth "as it is." For Rowland, attention to the earth "as it is" indicates a significant but overlooked way in which Enoch performs a theology of resistance. Pruszinski discusses this aspect of Enoch in more detail in his spatial analysis of Biblical apocalypse (Pruszinski 2019). Pruszinski compares the eschatological visions in Enoch to those in Revelation. He notes that while their content is in many ways similar, in Revelation the eschatological themes occupy a far 
greater portion of the text than in Enoch. By contrast, Enoch keeps the reader's gaze on the present, "[suggesting] a continual critical engagement with the material world" (Pruszinski 2019, p. 10).

Pruszinski points to a specific part of Enoch, "The Book of Parables," when analysing the text's "critical engagement with the material world." This portion of the text is a detailed and dazzling description of earth-life, astronomy and meteorological phenomena. Enoch pays particular attention to water throughout this revelation. Dew-the spirit overseeing this natural phenomenon-Enoch explains, has its "abode in the extremities of heaven" where it is inextricably connected to the "receptacle of rain" (Laurence 1838, vol. 58, p. 12). The cloud created by rain and "the cloud of the mist" go on to be united as "one gives to the other" (Laurence 1838, vol. 58, p. 12). When the spirit of rain "is in motion from its receptacle" within which it is contained, angels are responsible for opening the receptacle to "bring it forth" (Laurence 1838, vol. 58, p. 12). As rain is "sprinkled" all over the earth "it forms a union with every kind of water on the ground" and provides nourishment (Laurence 1838, vol. 58, p. 13). In this manner, we read in Enoch, the "quantity of rain" is regulated (Laurence 1838, vol. 58, p. 14).

Attention to place, however, is also evident in the more eschatologically oriented portions of the text analysed by Kiel. In "The Book of the Watchers" the prophet's role is not only to foresee the future destruction of the earth, but to observe its present nature and record it. A large part of the text of Enoch is devoted to describing what the prophet learns as he is taken on a tutelary voyage by the angels of God to witness the workings of the cosmos and learn its secrets. The prophet is conveyed on what Michael E. Stone describes as "ascent revelations" through the universe guided by spiritual beings (Stone 2015, p. 345). There are vivid descriptions of celestial travel as the text recounts one peculiar experience: "clouds" and "mist" invite Enoch to take flight as he is pressed on by "agitated stars" and "flashes of lightning" while the winds assist and accelerate his trajectory across the heavens (Laurence 1838, vol. 14, p. 9). In heaven, Enoch has a vision of walls and habitations constructed out of crystal, with floors of fire. He visits the "mouths of all the rivers" (Laurence 1838, vol. 17, p. 6) and learns about the winds that preserve "the foundation of the earth" (Laurence 1838, vol. 18, p. 1).

Paying attention to the skies and to the environment, in "The Book of the Watchers" Enoch is equal parts astronomer, meteorologist, and naturalist. Trees are of especial significance and attention to their well-being suggests an awareness of the damaging effects of deforestation typical of the time in which Enoch was written. As Kiel also observes, "Hellenistic warfare made extensive use of wood" which had a significant negative environmental impact (Kiel 2017, p. 44). The clearing of the forests of the Mediterranean is linked to the rise of urbanisation, but the environmental degradation that resulted from such practices usually explain its decline as well. Enoch makes geological observations of mountains and "a cataract composed as of many cataracts" (Laurence 1838, vol. 27, p. 3). The prophet documents forests and different types of trees that are of value, i.e., those that produce frankincense and myrrh (Laurence 1838, vol. 28, p. 2). In Enoch, the prophet describes seeing "large beasts" of different species, and birds of various "countenances and forms" that sing "with notes of different sounds" (Laurence 1838, vol. 33, p. 1). Enoch explains that it was the angel Uriel who taught the prophet all the regulations and operations of the stars and that he has committed to writing all their names, times, and seasons (Laurence 1838, vol. 33, p. 2). "The Book of the Watchers" ends with a blessing sanctifying the signs of the heavens as well as those who study them, since they allow one to observe the effects of God's power.

As John C. Reeves and Annette Yoshiko Reed observe, "The Book of the Watchers" did not only shape thinking about eschatology, for which the book is most well-known today (Reeves and Reed 2018, p. 11). "The Book of the Watchers" is also an early example of Jewish natural science, and an attempt to incorporate scientific thinking within the Jewish faith (Alexander 2002). Expanding upon Pruszinski's recent work, we argue that a central and overlooked dimension of Enoch is its attention to the environment through 
the study of its "signs" and seasonal changes which the author(s) of Enoch believed could inform the behaviour of humanity in a positive direction. In Enoch, the observation of the interruption of natural regularity indicates that humanity has erred in the same way as had the antediluvian giants. The study of nature's "signs" is therefore presented as essential to humans cohabiting with other earthly creatures.

While Enoch contains themes relating to the end times, the main revelation-the secret knowledge which is shown to the prophet on his journey through the earth and the heavens-is that of the world "as it is." Enoch does not become an insatiable giant, but rather learns "the positive aspect of the heavenly secrets from angels" (Stone 2015, p. 351). He becomes a natural philosopher urging his readers to pay close attention to the natural world, neither to consume it nor to desire its end, but "to consider and behold every tree" and understand its workings (Laurence 1838, vol. 1, p. 4). For Philip S. Alexander, Enoch is a Jewish Thales or Lucretius, discoursing on the nature of things (Alexander 2002). For Michael E. Stone, Enoch the celestial mystic becomes "virtually angelic' as his 'eyes and ears, his vision and hearing, can apprehend the celestial realm and so he can learn redemptive knowledge" (Stone 2015, p. 350). Indeed, included within Enoch is also a lengthy astronomical tract, the "Astronomical Book" (Laurence 1838, vol. 71, p. 1). This portion of Enoch details the movements of the seasons by observing the sun, moon and stars. It is the rhythm of the seasons that will be upended in the coming flood, when the "seed shall be backward" and "everything done on earth shall be subverted" (Laurence 1838, vol. 79, p. 4). Having witnessed all this, Enoch descends to earth to impart this knowledge to his son, Methuselah. Enoch is allowed to spend one year with his family to instruct them in the teachings he has received, after which he will ascend again to heaven. Enoch goes on to entreat Methuselah to "preserve" these books that he has written so that they will benefit "future generations" (Laurence 1838, vol. 81, p. 2).

So far, we have drawn on Biblical scholarship to support an alternative reading of apocalypse that locates a theology of resistance not only in eschatological themes but, equally, in the prophet's attentiveness and openness to the earth "as it is." There is also, however, a significant current in the philosophy of religion that should be mentioned. In his Gifford lectures, Givenness and Revelation, Jean-Luc Marion has argued that apocalypse, in its etymological sense of "unveiling," should be understood as a particular way of perceiving the world that elicits wonder, rather than as merely a prediction regarding the world's future (Marion 2016). His approach draws on phenomenology and is similar to Pruszinski's, though the most striking parallel is with Carmignac's form criticism. Like Carmignac, Marion interprets apocalypse as an account of the world being received and revealed. In apocalypse, writes Marion, the senses are "overwhelmed" by a phenomenon in such a way that it is experienced as "saturated" with meaning; as a result, the viewer's perspective changes from that of a "neutral observer" to something more participatory, where intentionality, instead of trying to possess the thing it perceives, undergoes what Marion calls an "anamorphosis" or "inversion" of perspective (Marion 2016, p. 7). Ordinarily, Marion argues,

[A person] will remain at the centre of a spectacle that consequently brings him [sic] only...invisible mirrors of his own solitary gaze. To reach another point of view and an axis for the gaze other than this necessarily idolatrous perspective implies an overturning of the entire phenomenal arrangement: the movement into a complete anamorphosis (Marion 2016, p. 108).

For Marion what distinguishes apocalypse from other forms of theological discourse is less the content of the visions shown to the prophet, and more the "overturning" of the "solitary gaze" that makes the visions possible in the first place. It is this "overturning" that Marion describes as "a complete anamorphosis." Through anamorphosis there is a change in perception. Where previously one looked at the world, attempting to grasp it with one's gaze, one is now looked at by the world, receiving its presence in a state of radical openness and connectivity. 
While Marion himself does not relate his idea of anamorphosis to environmental thinking, there are obvious parallels between the way a phenomenon in Marion's work "saturates" the senses, causing them to be "overwhelmed" and for the gaze to be "overturned," and the way the environment can overwhelm and confound us. As Christina Gschwandtner writes in a recent study of saturation in Marion's thought,

there is little reason why nature may not appear or give itself (or be given as) as saturated ... [Natural phenomena] impose themselves as anamorphoses, determining the place at which we must "stand" in order to "see" them. They are given and received, not produced or otherwise determined by us (Gschwandtner 2014, p. 80).

For Gschwandtner, the environment should be seen as a saturated phenomenon, and she cites several passages where Marion alludes to the structural similarities between sensing the environment and sensing God. At several points, Gschwandtner even compares apocalyptic - in Marion's sense of the term, as an anamorphosis of perception-explicitly to literary descriptions of the natural world. Though her references are American nature writers such as R. W. Emerson and Annie Dillard, her remarks have a strong bearing on the subject of this essay: "This possible 'saturation' of natural phenomena becomes particularly evident in the depiction of encounters with nature in much nature writing ... [those] involved in botanical, geological, ethological, ecological and geological research frequently witness to this sense of abundance or excess and acknowledge the limitations of their research" (Gschwandtner 2014, pp. 81, 90; cf. Gschwandtner 2013).

Though anti-theological in orientation, the literary critic and environmental philosopher Timothy Morton also makes use of Marion's concept of anamorphosis in a way that is highly relevant to our subject. Morton follows Garrard in rejecting the usefulness of apocalypse in environmental rhetoric (Morton 2018, pp. 212-13). At the same time, Morton's own account of what it means to "be ecological" draws on Marion's analysis of revelation. In Realist Magic: Objects, Ontology, Causality (Morton 2013), Morton adapts Marion's concept of anamorphosis when describing how we perceive reality. For Morton, anamorphosis relates to the "distortion," the "absence of a reference point," which "objects" elicit from the viewer (Morton 2013, p. 125). An "object" is the way a thing appears to the one who is looking at it. When an object arrests the senses, there is an experience of being overwhelmed, and of the object not conforming to one's preconceived ideas. Morton describes this by using Marion's concepts of the "saturated phenomenon" and "anamorphosis." Morton gives the example of a car crash, in which the "glass fragments" are "fresh objects" that appear "like a crack in the real," "[assailing] my senses". As a result of the crash, there is an "anamorphosis" of vision that changes our perception of seemingly familiar objects and makes us consider them anew. The state of openness and receptivity is amplified by the car crash, but Morton thinks openness and receptivity is elicited on some level all the time; it is just that one ordinarily is too distracted by other things to notice the world in all its arresting, "saturating," presence. What Morton elsewhere describes as "being ecological" is the practice of openness and receptivity that optimises the ability to be surprised and overwhelmed by things as they are (Morton 2018, pp. 214-15). Borrowing from Martin Heidegger, Morton calls this practice "attunement," translating the German Stimmung, "mood" or "tuning" (Morton 2018, pp. 103-88). Gschwandtner also makes the comparison between anamorphosis and Stimmung, arguing, a propos ecological thinking in Marion, that "one requires 'eyes to see', a kind of attunement to the phenomena" (Gschwandtner 2014, p. 85).

In this way, Marion's rethinking of apocalypse as an anamorphosis of the gaze helps to expand the alternative reading of apocalypse we have been sketching, and acts as a bridge between secular and religious modes of attunement. Apocalypse is about seeing the world differently and effecting a change in perception. As such, the theology of resistance associated with Biblical apocalypse is not necessarily temporal. While there is no denying that the content of apocalyptic visions is often (although not always, see Carmignac 1979) concerned with the ending of the world, understanding how those visions are generated 
is important. In Biblical apocalyptic, a theology of resistance is expressed in alternative visions of new world-orders. They are also, however, expressed in alternative envisionings of the world-orders that already are-the world "as it is." Those alternative envisionings and shifts in perception are what we have analysed using, first, the Biblical scholarship of Rowland and Pruszinski, and, finally, Marion's concept of apocalypse as the result of the gaze undergoing an "anamorphosis" that leaves it radically open to the world. In the final section, we will indicate some ways in which this reading can help us to rethink Garrard's criticism of the literary adaptations of Biblical apocalyptic in climate fiction.

\section{Apocalyptic as the Medium of Realist Imaginaries in Climate Fiction}

By exploring the argument that Biblical apocalypse is not necessarily temporal, we have been able to rethink Garrard's negative portrayal of the relationship between environmentalism and the apocalypse tradition. While Garrard's interpretation of environmentalism and the apocalypse tradition was based on readings of Jewish and Christian Biblical apocalyptic, however, his principal concern was apocalypse in climate fiction. Garrard's reading is ecocritical, and in this final section, we apply the alternative reading we have developed in dialogue with ecotheology, Biblical hermeneutics and the philosophy of religion, to some recent engagements with apocalypticism from the perspective of literary theory.

As Caroline Edwards argues in her study of apocalyptic in contemporary fiction, negative portrayals of the genre as escapist overlook the way in which climate fiction also contains astonishing examples of sustained, close observation of the environment. Edwards draws our attention to the peculiar combination of "speculative and realist literary imaginaries" found in contemporary flood fictions written in English, such as those by Kim Stanley Robinson (2017) and Margaret Atwood (2009). Edwards goes on to argue that the flood fictions of the twenty-first century "exert a utopian power to draw readers into tackling the difficult topics of climate change and global warming, helping develop an affective affinity with these pressing and increasingly apocalyptic issues in a way that nonfiction discourse cannot" (Edwards 2019, p. 235). Among the powers of apocalyptic climate fiction pointed out by Edwards is its ability to engage with the challenges of representing what Rob Nixon has described as the slowness and drawn-out time scales of the environmental crisis, especially when viewed from the perspective of the poor (Nixon 2013). Astrid Bracke echoes this sentiment in arguing that through "their depiction of floods as the result of-even synecdoches for-climate crisis, these works go some way toward tackling the imaginative and representational challenges of the Anthropocene frequently noted by scholars" (Bracke 2019, p. 279).

The narrative mechanisms of realistic apocalyptic imaginaries in climate fiction are fascinating and have been receiving increased attention from scholars of religion and literature. The recent work by Mebius (2018-2019) has shown the relevance of Enoch for understanding the relationship between speculation and realism in flood narratives from the eighteenth century onwards. Upon its rediscovery in the West by James Bruce in 1773, and the subsequent translation of Enoch into English by Richard Laurence, Enoch sparked numerous proto-environmentalist texts and works of art in Europe, the British Isles and North America. Through writing or imagining the antediluvian world, novelists, poets, as well as painters could draw attention to and scrutinise what they saw as the antediluvian ills of their own time. Speculative fiction here became a way to facilitate a shift in perception, re-attuning persons to the world and its traumas. Today, we are again experiencing an antediluvian moment. Life before the deluge is making its mark on twenty-first literature and art, just as it did in the nineteenth century in response to the environmental effects of the Industrial Revolution (Mebius 2018-2019). As Ewa Rychter has argued, Noah's deluge has become a primary reference point for many English-language novelists, and in recent times "the Flood has attracted more attention from British novelists than any other biblical narrative" (Rychter 2013, §1).

The role played by apocalyptic as a medium for realist as well as speculative imaginaries in British climate fiction is especially evident in Megan Hunter's recent The End We 
Start From (Hunter 2017). The novel draws explicitly on Biblical and other religious and mythical narratives of the Flood, which are interwoven into a first-person account of the disruption to ordinary life caused by rising sea-levels in the British Isles. The story begins as the unnamed narrator, Hunter's woman of the apocalypse, goes into labour. Hunter's female narrator shares many characteristics with Enoch and we quickly recognise the long tradition of Biblical and apocryphal apocalyptic prophecy to which she belongs. As a child, she believed she "had been chosen for our times. The ending times. The creeping times" (Hunter 2017, p. 3). At thirty-two weeks pregnant, her childhood suspicions seem to be confirmed: "the water is rising faster than they thought" (Hunter 2017, p. 3). After giving birth, the new family escapes to R's (the father's) childhood home in the mountains where they take up residence with his parents, who the reader knows as N and G. Life settles into a rhythm of days at home interrupted by $\mathrm{R}$ and his parents going out to gather supplies. One day, $R$ and his father, $N$, return without R's mother. No explanation as to what has happened is given, though it is suggested that $G$ died as a result of mob violence. Eventually the family is broken up. The narrator's husband abandons his wife and child and the narrator goes in search of refuge. She ends up forming a new family unit with another single mother, O. Together, the women negotiate refugee camps, and find a temporary haven on an island off the Scottish coast, before the narrator decides to return to London to look for her husband. The novel closes with the family reunited but deeply traumatised, struggling to rebuild their lives in the midst of a world changed beyond recognition.

The End We Start From combines eschatological themes with an acute attention to the details of the everyday life of those experiencing the flood. Interspersed throughout the narrative are passages of stirring myth, which contrast with the everyday life of the survivors. There is a painful sense of uncertainty as their daily life continues, as they engage the new baby in games, and as they share moments of touching domesticity. In this way, Megan Hunter's retelling of apocalypse relies on the familiar symbols and language of disaster, while avoiding a narrowly disaster-oriented story, that is, one that results in escapism from the world "as it is." Nor is domesticity here straightforwardly an escape from the horrors of the world "out there." Everyday life for the survivors is traumatic, as well as quotidian. At the beginning of the novel, the family spend their days eating in front of the TV watching reruns of talent shows. The baby is the centre of loving attention but also of anxiety and sorrow. Life during the disaster is dangerous and uncertain. The novel relates petty thieving, the loss of a parent to mob violence, depression, anxiety, and hunger.

Allusions to modernism inform the novel's attention to the real and the present. The novel takes its title from T. S. Eliot's Four Quartets, and the novel explores modernism's interest in states of heightened or altered perception. The narrator feels similar to "Aldous Huxley on mescaline" (2017, p. 5). Heightened awareness of the everyday, of the senses and of perception, characterise the narrative, which tells the story of disaster from the perspective of a single individual's stream of consciousness. Existence in the apocalypse is slow, and sometimes excruciatingly repetitive, but for that reason also attuned in a new and unfamiliar way to the present.

In The End We Start From, the narrator's motherhood and the baby's developmentsmiling, rolling over and pulling to stand-becomes a way of attuning to the slow tempo of disaster as experienced from the point of view of an otherwise almost claustrophobic domesticity. Even though these events are "incremental," "invisible," a "non-happening," they are also the only measure of time available:

Of course, he likes it when I cover myself in a tea towel, and reappear [...] I take a rug from the house and put $Z$ [the baby] on it. We sit in the rough field under the sky, which races away from us towards the happening.

We have arrived at the non-happening, it seems: the invisible growth of Z's body, the tiny increments of our meals coming out of the soil (2017, pp. 78-80).

Once the narrator is able to return home to London, the world that meets her appears strange. Where she envisaged "welcomes and tea, smiles and Blitz spirit, there is grey concrete, wailing people dragging themselves across the road, photo-boards of the missing." 
They live in a new shelter on the eighty-first floor. The narrator compares the bullet holes that mark the walls of the buildings to "fossils, punctured marks of a prehistoric life" (2017, p. 104). The new marks are both "brand new" and "aeons old" (2017, p. 104). The novel ends as the family is reunited. The husband is found in another shelter, and their home is now on the dry list. The narration of the family's return to their apartment is interrupted by passages that tell of birds bringing signs of dry land in their beaks: "One bird brought earth from the very bottom, caught in its beak like gold." However, whereas the birds finally found dry earth, the still-broken family finds an apartment covered in mould with rotting floors. The narrator puts her son down on the rotting wood and watches as $Z$ "lifts a leg and-impossible, impossible-he takes a step" (2017, p. 127).

Hunter's apocalypse provides a speculative fiction about a possible future that also formulates a heightened awareness of the present, both for the reader and the narrator. What is striking about The End We Start From is the relative absence of references to the climate disaster itself. Although Hunter's is an apocalyptic narrative, its "apocalypticism" cannot be construed narrowly as temporal. Applying the alternative reading of Biblical apocalyptic we have developed over the course of this article, we might say that Hunter not only deals with the temporal (thematic) eschatology common to apocalyptic, she also-and more importantly-performs the genre's (formal) "attunement" to the world through her domestic realism. In this way the realism of The End We Start From does not stand in contradiction to the speculative fiction that shapes its narrative arc. At the same time, the characters at the end of the novel are not the same as they were at the beginning of the story. The disaster has altered their, and the reader's, perception of the world, and in this way The End We Start From does address those fundamental questions of resistance and revolution central to apocalyptic-but from a perspective that is not narrowly temporal. Or rather, insofar as they allude to time changing, they situate these changes not only in geophysical events but in the slow and incremental steps that lead a child from supine to walking. These are indeed the end times, but, as Hunter's narrator defines them, they are "creeping" rather than cataclysmic.

Although The End We Start From is about a climate disaster, it does not cast itself as a "dramatic" text preoccupied with either utopian or dystopian visions of the future. Rather, it is a text about the everyday experience of disaster told in real-time from the perspective of domesticity. In this way Hunter's novel challenges the assumptions Garrard brings to his analysis of climate fiction. In a recent interview, climate fiction writer Kim Stanley Robinson has commented on these assumptions, which he sees informing many popular representations of apocalypse. Robinson admits that films about climate change often focus on single, cataclysmic events, but that many novels do not and that apocalypse in climate fiction is not necessarily focussed on temporality and the end of time. Commenting on what he calls the "realism" of apocalyptic climate fiction, Robinson explains that:

The biggest crisis in the story is thus not any weather event, but [...] a change of consciousness. For any of us that is always a big crisis. Now I think that the novel proper has the flexibility and capaciousness to depict any human situation, including ordinary life. That's what the modern novel was created to do, and that capacity never leaves it. It's only when you shrink the novel to the thriller that you run into problems in representing ordinary realities (Robinson and Canavan 2014, pp. 244-45, our emphasis).

By arguing that the "biggest crisis in the story" of climate change is not a single, cataclysmic weather event but a "change of consciousness" Robinson does not want to trivialise the reality of the threat of the geophysical crisis we face but rather root its implications more firmly in the lived realities of everyday life. An apocalyptic narrative of climate change centred on crisis is problematic, Robinson agrees, but only if apocalypse is construed narrowly as a story about cataclysmic events. Apocalypse is also the story of persons and readers learning to see the world differently as they become more aware of their environment. For Robinson, drawing attention to the role of that second story-the story of awareness being heightened and consciousness being changed-is something that 
the modern novel can do particularly well. Attention to the present is the overlooked aspect of apocalyptic climate fiction that justifies its continued relevance as an environmental literature.

There are striking parallels between Robinson's remarks and Hunter's approach to apocalypse in The End We Start From. Both address an alternative understanding of apocalypse that challenges the definition of apocalypse as temporal. In turn, this resonates with our rethinking of environmentalism and apocalypse from the perspective of Biblical scholarship and the philosophy of religion. Before God reveals the world's possible futures to the prophet, the world reveals itself to the prophet, who receives it in a state of radical openness as a result of a "complete overturning" of the gaze. It is this overturning of the gaze and "change of consciousness" to which both Biblical apocalypse and apocalyptic climate fiction ultimately bear witness.

Author Contributions: S.K. and E.-C.M. both contributed to the Introduction. S.K. was responsible for Section 2. Both S.K. and E.-C.M. contributed to Section 3. S.K. and E.-C.M. both contributed to Section 4. S.K. and E.-C.M. both revised the entire manuscript. Both authors have read and agreed to the published version of the manuscript.

Funding: S.K. received funding from the University of Oslo research project ECODISTURB.

Institutional Review Board Statement: Not application.

Informed Consent Statement: Not application.

Data Availability Statement: Not application.

Conflicts of Interest: The authors declare no conflict of interest.

\section{References}

Agamben, Giorgio. 2005. The Time That Remains: A Commentary on the Letter to the Romans. Stanford: Stanford University Press.

Alexander, Philip S. 2002. Enoch and the Beginnings of Jewish Interest in Natural Science. In The Wisdom Texts from Qumran and the Development of Sapiential Thought. Edited by Charlotte Hempel, Armin Lange and Hermann Lichtenberger. Leuven: Leuven University Press, pp. 223-44.

Assefa, Daniel. 2017. The Cry of the Earth in 1 Enoch and Environmental Theology. In The Blessing of Enoch: 1 Enoch and Contemporary Theology. Edited by Philip F. Esler. Eugene: Cascade Books, pp. 124-32.

Atwood, Margaret. 2009. The Year of the Flood. New York: Doubleday.

Bracke, Astrid. 2019. Flooded Futures: The Representation of the Anthropocene in Twenty-First-Century British Flood Fictions. Critical Studies in Contemporary Fiction 60: 278-88. [CrossRef]

Bruckner, Pascal. 2013. The Fanaticism of the Apocalypse: Save the Earth, Punish Human Beings. Translated by Stephen Rendall. Cambridge: Polity.

Callenbach, Ernest. 1975. Ecotopia: The Notebooks and Reports of William Weston. New York: Banyan Books.

Carmignac, Jean. 1979. Description du phénomène de l'Apocalyptique. In Apocalypticism in the Mediterranean World and the Near East: Proceedings of the International Colloquium on Apocalypticism. Edited by David Hellholm. Uppsala: Mohr, pp. 163-70.

Collins, John J., ed. 1979. Semeia 14: Apocalypse: The Morphology of a Genre. Atlanta: Society of Biblical Literature.

Collins, John J. 2016. The Genre Apocalypse Reconsidered. Zeitschrift für Antikes Christentum 20: 21-40. [CrossRef]

Dittmer, Jason, and Tristan Sturm, eds. 2010. Mapping the End Times: American Evangelical Geopolitics and Apocalyptic Visions. Farnham: Ashgate.

Edwards, Caroline. 2019. All Aboard for Ararat: Islands in Contemporary Flood Fiction. Association for the Study of the Arts of the Present 4: 211-38. [CrossRef]

Garrard, Greg. 2001. Environmentalism and the Apocalypse Tradition. Green Letters 3: 27-68. [CrossRef]

Garrard, Greg. 2012. Ecocriticism, 2nd ed. London: Routledge.

Goff, Matthew. 2010. Monstrous Appetites: Giants, Cannibalism, and Insatiable Eating in Enochic Literature. Journal of Ancient Judaism 1: 19-42. [CrossRef]

Gschwandtner, Christina. 2013. Might Nature be Interpreted as a Saturated Phenomenon? In Interpreting Nature: The Emerging Field of Environmental Hermeneutics. Edited by Forrest Clingerman Brian Treanor, Martin Drenthen and David Utsler. New York: Fordham University Press, pp. 82-101.

Gschwandtner, Christina. 2014. Degrees of Givenness: On Saturation in Jean-Luc Marion. Bloomington: Indiana University Press.

Hall, John. 2009. Apocalypse: From Antiquity to the Empire of Modernity. Cambridge: Polity.

Hunter, Megan. 2017. The End We Start From. London: Picador.

Keller, Catherine. 1983. Apocalypse Now and Then: A Feminist's Guide to the End of the World. Boston: Beacon Press. 
Keller, Catherine. 2018. Political Theology of the Earth: Our Planetary Emergency and the Struggle for a New Public. New York: Columbia University Press.

Keller, Catherine. 2021. Facing Apocalypse: Climate, Democracy, and Other Last Chances. Maryknoll: Orbis.

Kiel, Micah. 2017. Apocalyptic Ecology: The Book of Revelation, the Earth, and the Future. Minneapolis: Liturgical Press.

LaHaye, Tim, and Jerry Jenkins. 1995. Left Behind: A Novel of the Earth's Last Days. Wheaton: Tyndale House.

Richard Laurence, trans. 1838, The Book of Enoch the Prophet. Oxford: Oxford University Press.

Marion, Jean-Luc. 2016. Givenness and Revelation. Translated by Stephen Lewis. Oxford: Oxford University Press.

McNeish, Wallace. 2017. From Revelation to Revolution: Apocalypticism in Green Politics. Environmental Politics 26: 1035-54. [CrossRef]

Mebius, Eva-Charlotta. 2018-2019. Before the Deluge: Apocalyptic Floodscapes from John Martin to John Goto 1789 to Now. Exhibition. New Haven: Yale Center for British Art. Available online: https:/ / britishart.yale.edu/exhibitions-programs/deluge-apocalypticfloodscapes-john-martin-john-goto-1789-now (accessed on 27 July 2021).

Mebius, Eva-Charlotta. 2020. Living in Antediluvian Times: Apocalyptic Floodscapes in Literature and Art 1830-1895. Ph.D. dissertation, University College London, London, UK. Available online: https://discovery.ucl.ac.uk/id/eprint/10113824/ (accessed on 27 July 2021).

Megoran, Nick. 2013. Radical Politics and the Apocalypse: Activist Readings of Revelation. Area 45: 141-47. [CrossRef]

Moltmann, Jürgen. 1967. Theology of Hope. London: SCM Press.

Morton, Timothy. 2013. Realist Magic: Objects, Ontology, Causality. Ann Arbor: Open Humanities Press.

Morton, Timothy. 2018. Being Ecological. London: Pelican.

Nixon, Rob. 2013. Slow Violence and the Environmentalism of the Poor. Cambridge: Harvard University Press.

Northcott, Michael. 2007. An Angel Directs the Storm: Apocalyptic Religion and American Empire, 2nd revised edition. London: SCM Press.

Northcott, Michael. 2014. A Political Theology of Climate Change, 2nd ed. London: SCM Press.

Paik, Peter Yoonsuk. 2003. Smart Bombs, Serial Killings, and the Rapture: The Vanishing Bodies of Imperial Apocalypticism. Postmodern Culture 14: 1. [CrossRef]

Pannenberg, Wolfhart, ed. 1969. Revelation as History. David Granskou, and Edward Quinn, transs. London: Sheed and Ward.

Peifer, Jared, Elaine Howard Ecklund, and Cara Fullerton. 2014. How Evangelicals from Two Churches in the American Southwest Frame their Relationship with the Environment. Review of Religious Research 56: 373-97. [CrossRef]

Perkinson, James. 2015. Political Spirituality in an Age of Eco-Apocalypse: Communication and Struggle across Species, Cultures, and Religions. Houndmills: Palgrave Macmillan.

Portier-Young, Anthea. 2011. Apocalypse against Empire: Theologies of Resistance in Early Judaism. Grand Rapids: Eerdman.

Pruszinski, Jolyon. 2019. The Cognitive Phenomenology of Doors in the Book of Revelation: A Spatial Analysis. Religions 10: 194. [CrossRef]

Pruszinski, Jolyon. 2021. An Ecology of Scriptures: Experiences of Dwelling behind Early Jewish and Christian Texts. London: T \& T Clark.

Rahner, Karl. 1961. Theological Investigations. Berkeley: University of California, vol. 4.

Reeves, John C., and Annette Yoshiko Reed. 2018. Introduction. In Enoch From Antiquity to the Middle Ages, Volume I: Sources from Judaism, Christianity, and Islam. Edited by John C. Reeves and Annette Yoshiko Reed. Oxford: Oxford University Press, pp. 1-16.

Robinson, Kim Stanley, and Gerry Canavan. 2014. Still, I'm Reluctant to Call This Pessimism. In Green Planets: Ecology and Science Fiction. Middletown: Wesleyan University Press, pp. 243-60.

Robinson, Kim Stanley. 2015. Green Earth, Revised omnibus edition. London: HarperCollins.

Robinson, Kim Stanley. 2017. New York 2140. London: Orbit.

Rossing, Barbara. 2005. The Rapture Exposed: The Message of Hope in the Book of Revelation. New York: Basic Books.

Rossing, Barbara. 2007. Prophecy, End-Times, and American Apocalypse: Reclaiming Hope for Our World. Anglican Theological Review 89: 549-63.

Rowland, C. 1982. The Open Heaven: A Study of Apocalyptic in Judaism and Early Christianity. London: SPCK Press.

Rychter, Ewa. 2013. When the Novel Meets the Bible: The Flood in Four Contemporary British Novels. Caliban 33. [CrossRef]

Schneider-Mayerson, Matthew. 2018. The Influence of Climate Fiction: An Empirical Survey of Readers. Environmental Humanities 10: 473-500. [CrossRef]

Simmons, J. Aaron. 2009. Evangelical Environmentalism: Oxymoron or Opportunity? Worldviews 13: 40-71. [CrossRef]

Skrimshire, Stefan. 2019. Deep Time and Secular Time: A Critique of the Environmental "Long View". Theory, Culture E Society 36: 63-81.

Stone, Michael E. 2015. Enoch and the Fall of the Angels: Teaching and Status. Dead Sea Discoveries 22: 342-57. [CrossRef]

Stuckenbruck, Loren T. 2017. Words from the Book of Enoch on the Environment. In the Blessing of Enoch: 1 Enoch and Contemporary Theology. Edited by Philip F. Esler. Eugene: Cascade Books, pp. 111-23.

Trelstad, Maril. 2018. Death and Apocalypse in a Time of Fear. Dialog 57: 263-70. [CrossRef]

White, Lynn, Jr. 1967. The Historical Roots of Our Ecological Crisis. Science 155: 1203-07. [CrossRef] [PubMed]

Yusoff, Kathryn. 2018. A Billion Black Anthropocenes or None. Minneapolis: University of Minnesota Press. 